\title{
New Horizons for Health Care Analysis
}

\author{
John Coggon ${ }^{1}$ \\ Published online: 10 October 2018 \\ (c) Springer Science+Business Media, LLC, part of Springer Nature 2018
}

Five years ago, I took over from Dr. Andrew Edgar as editor of Health Care Analysis, a journal I had long admired. It was an honour to succeed Andrew, and I did so aiming to carry on the good work that he, and previous editors, had done. This included a commitment to continuing to stimulate breadth and depth of topic-specific studies, in particular through special issues of the journal, promoting scholarship by colleagues at all academic levels, from early career researchers through to long-established scholars, and encouraging an expansive analytical engagement with questions concerning health and health policy. Health Care Analysis' primary discipline is philosophy, and I have been delighted to advance its strong tradition of including studies that combine philosophical methods with, for example, original empirical research, legal and policy studies, and health care practice-oriented works.

Such diversity, depth, and richness are only sustainable thanks to the excellent scholarship contributed by the authors who submit their work to the Journal, and the time, advice, and encouragement that is so generously given by colleagues in the peer review process. This includes members of the Journal's editorial board, as well as many further members of the academic community whose commitment to the goods that derive from publishing has them contribute to the review process. I am extremely grateful to all who have helped in this.

My time as editor has been helped immeasurably by Andrew Edgar's ongoing support. I am in equal measure deeply thankful to have enjoyed the guidance and advice of Dr. Jonathan Ives, Dr. Sorcha Uí Chonnachtaigh, and Dr. A.M. Viens: as scholars, they reflect the profound academic excellence and exciting breadth of analysis that can be found in humanities, social sciences, and health; in their roles as associate editors, they have been invaluable sources of wisdom, allowing the Journal to sustain its great rigour and reach. As well as this fantastic intellectual support, I am most pleased to record my gratitude to the staff at Springer, whose professionalism and efficiency have been unfaltering, for me and for authors and guest editors.

It is excellent that from 2019 the editorship of Health Care Analysis will move to A.M. Viens. Adrian knows the Journal well, having served it so generously over the past years on the editorial board. His own scholarship, rooted in philosophy, and

John Coggon

John.Coggon@bristol.ac.uk

1 Centre for Health, Law, and Society, University of Bristol, Bristol, UK 
applied at multiple disciplinary intersections and points of practice and policy, make him a pre-eminent person to advance the Journal's agendas. Health Care Analysis will strengthen and flourish further under Adrian's stewardship.

\section{Compliance with Ethical Standards}

Conflict of interest No conflict of interest to declare. 